\title{
The Absolute and the Relative in Lukács and Simmel
}

\section{Lukács and Simmel, a Century Later}

As the once-bitter disputes within and between $20^{\text {th }}$-century Marxist theory have receded into the gallery of historical images of spirit, the distance of time has allowed us to see beyond the shallow and often uncharitable reception of Lukács's work. ${ }^{1}$ Indeed, his philosophy has been brought back to life, although not necessarily as a unitary whole or even a succession of coherent positions. Rather, as readers have discovered new conceptual structures, aporias, occluded connections and historical meanings, Lukács's life work - via the mediation of sensitive and thoroughgoing scholarship - has proven capable of generating new truth.

The most significant contributions - by Andrew Feenberg, Konstantinos Kavoulakos and Richard Westerman - have read Lukács's pre-Marxist and 1920s works in light of his contemporary neo-Kantian philosophical influences in order to recover his own philosophy of praxis,
This chapter builds on the author's earlier Hegelian critique of Lukács's philosophy of praxis by construing a conceptual dialogue between Lukács and his one-time mentor, Georg Simmel. It is argued that Lukács's philosophy in the 1920 s was partially formed as a metacritique of Simmel's absolute relativism, as expressed in The Philosophy of Money. However, Lukács's alternative generates a conceptual mythology that can be diagnosed in Simmelian terms and sublated by the philosophy of life outlined in The View of Life. By situating it in the present, this may de-reify Lukács's concept of praxis, allowing it to satisfy its ethical and rational duty. 
of course articulated in the manner they find most coherent. ${ }^{2}$ My own work - primarily Lukács: Praxis and the Absolute - has taken a different path by immanently reconstructing the conceptual structure of Lukács's philosophy of praxis, to radicalise his Hegelian inheritance. In this manner, I identified what I regard to be the central aporia (or, in his own language, conceptual mythology) in Lukács's 1920s work. By driving his concept of praxis to its limit, I claim to have effected an overcoming of Lukács, in which the one-sided truth of his implicitly speculative philosophy can be preserved only by a conscious shift to the standpoint of speculative (which is to say, Hegelian) philosophy proper. ${ }^{3}$

This chapter extends upon my earlier argument by way of Lukács's one-time mentor, Georg Simmel. Lukács's debt to the neo-Kantian social theorist and philosopher has not been explored in anywhere near the same detail as Lukács's debt to Marx, Hegel or to other neo-Kantians. Although Simmel's influence is generally noted in passing, critics commonly restrict their comments to a brief summary of Simmel's understanding of the "forms of objectification " and Lukács's critique thereof, which placed the commodity, understood in Marxian terms, at the centre of the social totality, instead of money or other heuristics. ${ }^{4}$ This is no doubt partly due to Lukács's own fairly hostile evaluation of Simmel and perhaps also because Simmel has generally been received as a sociologist, and is rarely considered a philosopher in his own right.

This contribution cannot rectify this omission wholly. Instead, I will construe a conceptual dialogue between Lukács and Simmel, in order to demonstrate that the deepest philosophical problems Lukács considered in History and Class Consiousness were framed in partial opposition to what he viewed as the antinomic and contemplative meaning of Simmel's thought. My method will not be philological: investigating the lineage of a given term or problematic is not the royal road to conceptual truth, especially when dealing with philosophers who brought their own subjective cultivation and convictions to bear on shared historical-intellectual problems, and who were not as strict with terminology as they might have imagined. Instead, I will highlight conceptual affinities while also proposing the point where Simmel and Lukács parted company. This will begin with a discussion of Simmel's doctrine of absolute relativism, as outlined in The Philosophy

2 Feenberg: The Philosophy of Praxis; Kavoulakos: Lukács's Philosophy of Praxis; Westerman: Lukács's Phenomenology of Capitalism.

3 The most concise summary of this standpoint is to be found in Rose: From Speculative to Dialectical Thinking.

4 See Kavoulakos: What is Reification in Georg Lukács's Early Marxist Work? 
of Money. Following a short evaluation of Lukács's explicit, quite critical comments about Simmel, it will be demonstrated that a highly Simmelian problematic - namely, the opposition between absolute and relative truth deeply informs Lukács's famous essay, The Antinomies of Bourgeois Thought.

Lukács rejected relativism, which ultimately reduces logic to aesthetics and renders the movement of history as a succession of incomparable yet qualitatively distinct value-paradigms. But he equally rejected absolute idealism, which he claimed erects a schematic logical-conceptual whole that is necessarily divorced from history and is, therefore, ultimately meaningless and still. As I have argued elsewhere, Lukács overcame these antinomies with a philosophically informed and politically radical concept of praxis that was supposed to unite logic (a dialectically-ordered conceptual totality) and genesis (the conceptual movement of history). ${ }^{5}$ The proletariat, its party and the workers' state were the bearers of this concept of praxis - and Lukács hoped that their self-conscious, practical and transformative intervention into history would, for the first time, create a society in which new contents could be grasped by a democratic, collective consciousness by virtue of its ongoing de-reification of the forms of social objectivity. This is to say, while Lukács wished to preserve the truth-claims of Hegel's absolute, he wished to divest them of their philosophical form and invest them instead in a collective revolutionary agency. This was the key to his overcoming of the contemplative, Kantian structure of bourgeois thought - Simmel included - with a de-sublimated, Marxist version of Hegel's absolute knowing.

Ethically speaking, Lukács's philosophy of praxis sought to chart a path between the reified, individualised »contemplative stance ${ }^{6}$ endemic to bourgeois society, and a way of life through which the individual might reconcile with the universal, without being obliterated by it or subsuming it under their particularity. That is, Lukács sought a polity that could sustain reconciliation between subject and object. As I have argued, his solution broke down, revealing itself to be a conceptual mythology. ${ }^{7}$ This, paradoxically, pushes Lukács's philosophy - albeit unknowingly - back to a tragic, theological standpoint he had already encountered in Soul and Form. This was equally an intellectual stance and style of life analysed by Simmel, described in The Philosophy of Money as the "sanguine enthusiast ${ }^{8}$ and

5 López: Lukács. The Antinomies of Bourgeois Philosophy.

6 Lukács: History and Class Consciousness, p. 89 (»contemplative Haltung «, Geschichte und Klassenbewußtsein, pp. 264).

7 See López: Lukács. Praxis and the Absolute, Ch. 9.

8 Simmel: The Philosophy of Money, p. 275 (»sanguinischer Enthusiast«, Philosophie des Geldes, p. 264). 
in his essay The Conflict of Modern Culture, in more radical form, as the "ascetic saint «. ${ }^{9}$ As Lukács knew well, the essentially romantic disposition underlying the sanguine enthusiast and the ascetic saint denotes a form of the contemplative stance which obliterates the object under messianically overextended subjectivity. For this reason, it makes impossible any true interrelation between means and ends or between self and other, rendering the goal of ethical action tragic. This, in turn, posits truth dualistically: on the one hand as an inaccessible, transcendent whole that is unknowable, and on the other, as an irrational, aesthetic and ultimately faith-driven subjective conviction. An estranged `ought always betrays what >is . While Lukács himself escaped the cul-de-sac in which his 1920s philosophy found itself by way of a turn to orthodoxy in the 1930s, this accusation - if upheld - implicates his philosophy of praxis in a fatal ethical and logical self-contradiction. This also, I believe, demonstrates the immanent limit of all praxis-oriented Marxism.

However, rather than repeating this critique of Lukács, this chapter will instead propose a Simmelian alternative to the antinomic structure of Lukács's philosophy of praxis. While groundwork exists in Simmel's earlier writings, this will be drawn primarily from his final work, The View of Life, in which he proposes to overcome the bifurcated modern standpoint with a philosophy of life. It will be suggested that this solution has a broadly speculative (in the Hegelian sense) structure as it overcomes the dualisms of life not by predicting (or agitating for) a new form of life that may restore the fragmentary to wholeness. Rather, Simmel proposes a sphere of self-reflective knowledge - philosophy - that can provide a vantagepoint from which to traverse, analyse and reconcile the antinomies of modern life and thought. As a philosophical vantagepoint, the speculative standpoint is contemplative and individual - but this certainly does not forbid the speculative philosopher from intervention into the world of from joining and shaping collective projects, should that be her or his proclivity. What this standpoint does promise, however, is practice of knowing whereby we may learn to traverse what Bloch evocatively called »das Dunkel des gelebten Augenblicks $« .{ }^{10}$ In more Hegelian terminology, this figure of thought has grasped the finitude and non-being of every being, both real and conceptual, and has understood that the passing over of every discreet thing into another is its negation and equally the movement of the true infinite. As Hegel writes:

9 Simmel: The Conflict of Modern Culture, p. 64.

10 See Bloch's review of Lukács' Actuality and Utopia, printed in Moir: The Archimedean Point, p. 22. 
[T] he truth of the finite is rather its ideality. [...] This ideality of the finite is the chief proposition of philosophy, and every true philosophy is for that reason idealism. The only thing that matters is not to take as the infinite what is at once made into something particular and finite in the determination of it. ${ }^{11}$

For a Lukácsian philosopher of praxis to inhabit this standpoint, they must divest praxis of the burden of absolute knowledge and instead cultivate the philosophical practice of absolute knowing. This may liberate praxis, as well as the philosopher, from a subjectively overdetermined, antinomic and ultimately tragic irrationalism which transforms praxis into an ought, or, an infinitely distant truth towards which we dutifully strive. If the acting consciousness - the philosopher of praxis - can forgive and accept forgiveness from the judging consciousness - the speculative philosopher - there a self-reflexive spiritual knowledge may appear, namely, speculative Marxism. ${ }^{12}$ In conclusion, I will propose a few further consequences that follow for Lukácsian Marxism, and for Marxist philosophy in general, should this speculative, Simmelian proposal hold.

\section{Simmel's Absolute Relativism}

From the references to Simmel in History and Class Consciousness, it seems clear that Lukács regarded The Philosophy of Money as the definitive statement of Simmel's philosophy. This is also where Simmel outlines his most comprehensive account of absolute relativism, his own philosophical position, at least prior to Lebensanschauung ${ }^{13}{ }^{13}$ Methodologically, The Philosophy of Money combines philosophy and aesthetics. As Simmel explains in the 1907 Preface, philosophy, is more fundamental than the particular sciences because it moves fluidly from concepts to the »totality of life «. ${ }^{14}$ This movement between the abstract and the concrete suits money, a unique social object that universally equates qualitative values. Simmel explained the role of aesthetics in his methodology, noting that the

great advantage of art over philosophy is that it sets itself a single, narrowly defined problem every time: a person, a landscape, a mood. Every extension of one of these to

11 Hegel: Encyclopedia of the Philosophical Sciences in Basic Outline, Part I: Science of Logic, \$. 95.

12 Gillian Rose called first for a speculative Marxism. This chapter seeks to contribute to that project. See Rose: Hegel Contra Sociology, pp. 223-226.

13 This should not be taken to imply that Simmel's position prior to >Lebensanschauung $<$ is unchanging or that other works, for example, Schopenhauer and Nietzsche, do not add important details to the picture.

Simmel: The Philosophy of Money, p. 53 (»Totalität des Lebens«, Philosophie des Geldes, p. VIII). 
the general, every addition of bold touches of feeling for the world is made to appear as an enrichment, a gift, an undeserved benefit. ${ }^{15}$

This is how Simmel justifies his decision to nominate money as an ideal structure, or a heuristic, with which to illuminate the whole. Philosophy holds the implicit arbitrariness of his heuristic at bay with the infinite reciprocity of reasonable scrutiny. The result is a conceptual genesis of money. ${ }^{16}$ As an aside, this is worth noting given the centrality Lukács accords to conceptual genesis, as the historical dimension of dialectical thought. ${ }^{17}$

Subsequently, in the first, analytic, section, Simmel builds an ideal anthropology of value in order to elucidate its subsequent genesis, eventually objectified in money. Initially, value is a spatial relation between people and things that is not reducible to either pole. Without people, no object is valuable and the value something holds for one person is only a part, at best, of its full value. In addition to this, value has a temporal dimension: To value something, we imagine a future in which the valued object is possessed and enjoyed..$^{18}$ Yet as the object of desire is obtained and consumed, the future becomes the past and new desires are born, giving rise to new acts of valuation. So, while value cannot be extricated from these poles, between subjects and object or past and future, it is a "third term, an ideal concept which enters into the duality but is not exhausted by it.$^{19}$ Value is born in and helps us to define this tension, and this is what gives value a metaphysical or ideal quality.

Exchange is the practice that creates value: »By being exchanged, each object acquires a practical realization and measure of its value through the other object. $\ll^{20}$ This holds even when an exchange seems gratuitously unequal. Nevertheless, as acts of exchange proliferate, the objective standards they produce are embodied in standardized values and eventually, money, which represents value in a formally universal manner, that is, numerically. Indeed, as Simmel argues, "money is the reification of exchange among peo-

15 Ibid., pp. 55-56 (»Der ungeheure Vorteil der Kunst gegenüber der Philosophie ist, daß sie sich jedesmal ein einzelnes, engumschriebenes Problem setzt; einen Menschen, eine Landschaft, eine Stimmung - und nun jede Erweiterung desselben zum Allgemeinen, jede Hinzufügung großer Züge des Weltfühlens, wie eine Bereicherung, Geschenk, gleichsam wie eine unverdiente Beglückung empfinden läßt.«, Philosophie des Geldes, p. VIII).

16 Ibid., p. 54 (Philosophie des Geldes, p. VII).

17 Cf Lukács: History and Class Consciousness, p. 141. For a further discussion of Lukács's concept of genesis, see López: Lukács. The Antinomies of Bourgeois Philosophy.

18 Simmel: The Philosophy of Money, p. 74 (Philosophie des Geldes, p. 19).

19 Ibid., p. 70 (»[...] sie ist vielmehr ein Drittes, Ideelles, das zwar in jene Zweiheit eingeht, aber nicht in ihr aufgeht.", Philosophie des Geldes, p. 14).

20 Ibid., p. 81 (»Denn indem sie gegeneinander ausgetauscht werden, gewinnt jeder die praktische Verwirklichung und das Maß seines Wertes an dem anderen. «, Philosophie des Geldes, p. 28). 
ple, and the embodiment of pure function $\ll{ }^{21}$ Of course, many other social practices separate themselves from their human origins: communication, for instance, is objectified in language. But money is special because of its indifference. While language is tied with cultures and nations, money is a uniquely abstract universal mediator.

Although he identifies exchange as a fundamental human capacity, Simmel is careful to avoid making exhaustive claims about human nature. Because he sees money (and underlying it, exchange) as ultimately founded on a subjective valuation made between people, there is no need to defend an ontological substrate from which they derive their objectivity or to see them as expressions of an inner essence, like labour. ${ }^{22}$ Insofar as an epistemological standpoint is needed, Simmel's approach gives ontological primacy to the present: Because modernity has perfected money, it is possible to posit a trans-historical anthropology of exchange while also using it to illuminate modern culture, as Simmel does in essays like Metropolis and Mental Life or The Adventurer. ${ }^{23}$ His is also a historicist approach. As a monetary societies extend the »teleological chain « - the distance between means and ends - by way of long trade networks, credit and other mechanisms, money transforms the way we perceive time on a grand scale, giving us an enhanced ability to plan, trade, to save and to invest. ${ }^{24}$ This extends our capacity to represent the past and the future in non-mythological or non-theological terms. ${ }^{25}$ This is also a perfect example of Simmel's metacritical sociological method: His chosen heuristic makes it possible to historically relativise the immediacy of the prevalent forms of social objectivity.

Simmel did not glorify the monetary economy; many of his comments are redolent of Lukács's own, humanistic critique of the fragmenting logic of reification. ${ }^{26} \mathrm{He}$ did, however, prefer to avoid explicit politically interventionist diagnoses. Philosophically, Simmel's approach fit with the fashion of German neo-Kantian academia which, having been burned by the $19^{\text {th }}$-century quest for first premises, instead declined to inquire as to their epistemological foundations or the truth of the whole. ${ }^{27}$ Nevertheless,

21 Ibid., p. 185 (»Die Doppelnatur des Geldes [...] gründet sich darauf, daß es nur in der Hypostasierung, gleichsam in der Fleischwerdung einer reinen Funktion, des Tausches unter Menschen, besteht. «, Philosophie des Geldes, p. 162). 
his defence of absolute relativism speaks to a growing crisis of meaning. Not content with limiting himself to partial inquiries, he is notable among his generation of anti-positivist sociologists both for his attention to the absolute, as a figure of thought, and his effort to ground his philosophical account in social theory and history. While freely admitting the ultimate baselessness of his philosophy of money, Simmel observed that even partial and modest truths presuppose greater and more essential truths. For even a limited statement to be true, it must rely on an infinite series of dependent assumptions and statements. And yet, if one truth is discovered to be false, the critical reason that proved the point sticks around afterwards, presupposing itself to be true, albeit negatively.

This metaphor resembles the economy: A totality of true statements is truer than one, in the same way as an economy is greater than the sum of the transactions that create it. Or, alternately, if one currency collapses, exchange as such is not implicated - and so, if critique is the last truth standing once all others have collapsed, it implies that critique is the ultimate, contentless truth. Thus, we are given two apparent dead ends: the elusive foundation of truth, on the one hand, and the unknowable totality of truth on the other. To begin with the latter, while we might posit that the totality of truths is superior to separate truths, this totality is unknowable: To render it as a mathematical whole, the sum total of extant truths, renders it as static and dooms it to supersession. The search for foundations, on the other hand, is too quick - every new candidate is superseded quickly by the newest, least dogmatic concept on the intellectual market. Philosophically speaking, the first path leads to dogmatism and the second to relativism. Both, however, regard »truth [as] a relative concept like weight $«{ }^{28}$ Neither can escape the nihilistic conclusion that every truth is untrue.

Simmel also rejected pragmatic solutions to this dilemma, which propose that instead of searching for true answers, we should search for useful ones. After all, usefulness must be measured against some other ends. For example, to assess claims in terms of what is useful for life assumes the necessity of life. But as Simmel notes the »existence of real life is not necessary in terms of any law; it would not contradict any logical or natural law if nothing existed $« .{ }^{29}$ Instead, Simmel proposed his own method - namely, positing heuristics that are admitted to contain an element of falsehood but

29 Ibid., p. 116 (»Daß überhaupt eine Wirklichkeit da ist, wird durch kein Gesetz notwendig gemacht, keinem logischen oder Naturgesetze wäre widersprochen, wenn es überhaupt kein Dasein gäbe.«, Philosophie des Geldes, p. 73). 
that facilitate the growth of knowledge through different successive (and potentially simultaneous) investigations.

This strategy has advantages. For one, it allows for paradigm shifts. Similarly, a moment of certainty (required in order to establish a new heuristic) is permitted critically, thereby guarding against dogmatism. Foundational assumptions are allowed domicile insofar as they pay rent by delivering knowledge. Still, relativism »shows that it is vain to consider any one of these viewpoints as definitive«; every certainty will eventually be evicted from the house of science. ${ }^{30}$ His conclusion is that "truth is valid, not in spite of its relativity but precisely on account of it «. ${ }^{31}$ Thus, the goal of truth transforms into the process of inquiring after truth - and whether one is satisfied with this no longer depends on an external standard, but whether one can be reconciled with the impermanence of truth. At least, Simmel consoled himself, this cultivates an openness to the extremes of life: »Then again it seems more admirable, and indeed the very challenge of life, to experience joy and sorrow, strength and weakness, virtue and sin as a living unity, each one being a condition of the other, each sacred and consecrating the other. $"$ " 2 Yet the question is raised: Why seek the truth if it is infinitely distant? The tragedy of Simmel's philosophy, in these years, was that he made the mind the object of its own inquiry, realising that the individual's quest for truth would inevitably fail, revealing itself to be as perniciously circular as the movement of objective truth. ${ }^{33}$ In the 1910s, Simmel found no way out of this ever-expanding circle of finite knowledge.

\section{Lukács's Marxian Metacritique of Simmel}

The particulars of Lukács's relationship with Simmel are fairly well known. During the 1910s, Lukács attended Simmel's lectures in Berlin and formed an intellectual friendship with him, internalising his outlook to a large extent. The elder Lukács described his manuscript on the Entwicklungsgeschichte des modernen Dramas as espousing a »truly [...] Simmelian philosophy «. ${ }^{34}$ den definitiven gewinnen zu wollen [...] «, Philosophie des Geldes, p. 74).

31 Ibid., p. 123 (»Dort gilt die Wahrheit, trotzdem sie relativ ist, hier gerade, weil sie es ist.«, Philosophie des Geldes, p. 82).

32 Ibid. (»Und dann wieder erscheint es einem als die Größe, ja die eigentliche Aufgabe, Lust und Leid, Kraft und Schwäche, Tugend und Sünde als e i n e Lebenseinheit zu fühlen, eines die Bedingung des anderen, jedes weihend und geweiht.", Philosophie des Geldes, p. 75, Hervorhebung D. A. L.). Ibid., p. 125.

34 Lukács: Selected Correspondence, 1902-1920, p. 14. 
Simmel himself seemingly corroborated this assessment in a 1909 letter, in which he enthusiastically endorsed Lukács's methodology, despite politely declining to critically review the manuscript. ${ }^{35}$ Indeed, Lukács's essays in Soul and Form grapple further with the distinctly Simmelian tension between form and life, albeit in a far more personal and immersive fashion that eschewed Simmel's urbane, sociological value neutrality. ${ }^{36}$ At the same time, however, as early as 1906, Lukács expressed private hesitations about what he experienced as the "weightless and sterile " atmosphere he encountered in Simmel's milieu. ${ }^{37}$ Simmel's support for the First World War placed further distance between him and Lukács. Given the latter's ethically charged decision to join the Hungarian Communist Party in 1918, as well as the ethical concerns of Lukács's early Marxist writing, it is doubtless that he felt a duty to explain the connection between Simmel's conservative stance and his philosophical outlook. As Löwy recounts, as Lukács grasped the »imperialist nature of the war «, he renewed his interest in Marx, seen this time through »Hegelian rather than Simmelian spectacles «. ${ }^{38}$

Thus in his 1918 obituary of Simmel, Lukács described him as the philosopher of impressionism and as possessing a »methodological pluralism « that while »holding firm to the absoluteness of every [categorical] positing «, was hostile to any point of view that would »embrace the totality of life.$^{39}$ These critical comments are extended in History and Class Consciousness, where Lukács accuses Simmel of having produced an intellectually reified view of capitalist social relations, granting agency and power to bourgeois forms of objectivity and thus debarring the possibility of a praxis that may reshape the world consciously. This, he asserts, condemns Simmel to go no "further than a description «, with the consequence that his ")deepening of the problem runs in circles around the eternal manifestations of reification $«{ }^{40}$ Later in the book, Lukács argues that this traps Simmel within antinomies that cannot be overcome, but only wrenched further apart, thus debarring him from grasping the key mediation that might overcome reification (the praxis of the proletariat) and effectively abolishing history.

35

36

Ibid., p. 93.

Lukács: Die Seele und die Formen; Yoon Sun Lee has explored the persistence of the Simmelian antinomy between form and life, as it occurs throughout Lukács's whole career. See Sun Lee: Temporalized Invariance.

37 Gluck: Georg Lukács and his Generation, p. 147.

38 Löwy: Georg Lukács, p. 123.

39 Lukács: Georg Simmel, pp. 146-148.

40 Lukács: History and Class Consciousness, p. 95 (»Sie kommen aber damit über die bloße Beschreibung nicht hinaus und ihre >Vertiefung` des Problems dreht sich im Kreise um die äußerliche Erscheinungsformen der Verdinglichung.«, Geschichte und Klassenbewußtsen, p. 270). 
And even if this antinomy [between subject and object] assumes increasingly refined forms in later times so that it even makes its appearance in the shape of historicism, of historical relativism, this does not affect the basic problem, the abolition of history, in the slightest. ${ }^{41}$

I have discussed the debt that Lukács's concept of reification owes to Simmel elsewhere. ${ }^{42}$ Rather, what I wish to point out here is that the dialectical-historical progression of concepts that Lukács discerns in classical German Idealism, in the section of History and Class Consciousness's central essay entitled The Antinomies of Bourgeois Thought, grapples with precisely the same problematic that concerned Simmel in the sections of The Philosophy of Money summarised above. As I have undertaken a critical reading of this material elsewhere, I absolve myself of the necessity to reconstruct this remarkable essay once more. ${ }^{43}$ What matters, however, are the key conceptual transformations that Lukács identifies, what they share with Simmel and where they diverge. Firstly, Lukács proposes that German Idealism began with the founding conviction that we have made the objective world and consequently, that it may be known rationally, in its totality. ${ }^{44}$ This is a grander claim than Simmel's more modest conceptual genesis. Still, Simmel does posit an originary social practice - exchange - from which value emerges. It is simply more modest and self-critical. Lukács explains this difference in historical terms, proposing that classical German Idealism emerged in the twilight of the bourgeoisie's heroic age. Consequently, it had not given up on the universalism of reason, unlike the more cynical or demoralised neo-Kantian philosophers with whom Lukács had broken, Simmel included.

The antinomies that Simmel outlines in his account of relativism, Lukács identifies via Kant. He argues that the demand to universalise reason drives towards two contradictory extremes: the whole (or the totality), which concerns the ultimate objects of knowledge and the part (the thing in itself), which constitutes the ground of knowledge..$^{45} \mathrm{~A}$ little later, he reframes this problem as the tension between the form of reason and its irrational contents. Like Lukács, Simmel, as we have seen, declined to hypostatise either side, refusing to attribute truth to either a formal, mathematical totality or to abandon the question of truth by delimiting a partial sphere of rationality

41 Ibid., pp. 156-157 (»Und wenn diese Antinomie auch in späteren Zeiten immer verfeinertere Formen annimmt, ja sogar als Historismus, als historischer Relativismus auftritt, so ändert dies an dem Grundproblem selbst, an der Aufhebung der Geschichte gar nichts.", Geschichte und Klassenbewußtsein, p. 340).

42 López: Lukács: Praxis and the Absolute, Chs. 1 and 2.

43 See ibid., Ch. 8, and López: Lukács. The Antinomies of Bourgeois Philosophy.

44 Lukács: History and Class Consciousness, p. 112 (Geschichte und Klassenbewußtsein, p. 288).

45 Ibid., p. 115 (Geschichte und Klassenbewußtsein, p. 291). 
from its irrational substratum. Lukács overcomes this impasse by turning to Fichte who, in his account, radicalised practical reason, nominating the originary ethical act of the ego as constitutive of objectivity. ${ }^{46} \mathrm{Simmel}$, too, considered this Fichtean approach. He wrote:

And finally, to take a more comprehensive view: modern idealism produces the world from the Ego. The mind creates the world - the only world that we can discuss and that is real for us - according to its receptivity and its ability to construct forms. But on the other hand, this world is also the original source of the mind. [...] Considered historically, the mind with all its form and contents is a product of the world - of the same world which is in turn a product of the mind because it is a world of representations. ${ }^{47}$

Lukács would have agreed with Simmel when the latter said that if »these two genetic possibilities are rigidly conceptualized they result in a disturbing contradiction . $^{48}$

However, the two begin to diverge in the way they overcome this dilemma. Lukács, having derived a principle of creative human activity by way of Schiller, turns ultimately to Hegel, who elevated the basic antinomy in question to what Lukács regards as its highest philosophical expression, the opposition between >genesis` and $>\operatorname{logic} \triangleleft{ }^{49}$ In this formulation, genesis takes a different meaning to that which Simmel accords it: In Lukács's Hegelian account, genesis denotes the conceptuality of history as it moves rationally, albeit in estrangement from its human origins. Logic refers to an ordered and dialectical conceptual totality, in which terms are dynamized and deeply interrelated..$^{50}$ The dynamization of logical categories strains towards history, while the inner rationality of history strains towards logic. Yet, the contradiction between these two terms threatens to ruin both sides. Without dialectical logic, the genesis of history cannot be understood rationally, thus leaving us with a historical relativism that abolishes history in the flux of qualitatively distinct but irrational contents. And without grasping the historical genesis of the present, dialectical logic freezes over and becomes

Ibid., pp. 123-124 (Geschichte und Klassenbewußtsein, pp. 301-302).

Simmel: The Philosophy of Money, p. 119 (»Und endlich, noch weiter ausgreifend: der neuzeitliche Idealismus leitet die Welt aus dem Ich ab, die Seele erschafft, gemäß ihren Rezeptivitäten und produktiven Formungskräften die Welt, die einzige, von der wir sprechen können und die für uns real ist. Andrerseits aber ist diese Welt doch der Ursprung der Seele. [...] Wenn wir historisch denken, so ist die Seele, mit all ihren Formen und Inhalten, ein Produkt der Welt - eben dieser Welt, die doch, weil sie eine vorgestellte ist, zugleich ein Produkt der Seele ist.", Philosophie des Geldes, p. 77).

Ibid.

9 The famous final chapter of Die Phenomenologie des Geistes on Absolute Knowledge vindicates Lukács's interpretation of the centrality of these terms in Hegelian philosophy. See Hegel: Die Phenomenologie des Geistes, \$\$. 804-808.

50 López: Lukács. The Antinomies of Bourgeois Philosophy, pp. 121-124. 
schematic. So, Lukács famously nominated the praxis of the proletariat as the mediation between these two philosophical opposites, as the real-world principle whereby the opposition between the absolute and the relative could be overcome for good. Simmel's strategy is markedly more modest. He asserts that the »disturbing contradiction « between ego and world can be avoided »if they are regarded as heuristic principles which stand in a relationship of alteration and interaction $"{ }^{51}$ Lukács, to the contrary, in his critique of Schiller, firmly rejected the aesthetic foundation upon which all heuristic devices, including Simmel's, rested. He argued that any philosophy with aesthetics at its base either risks aestheticizing the world (and annihilating action) or mythologising creation, and thus conceding fatally to irrationalism. ${ }^{52}$ Given the extent to which Lukács, in his pre-Marxist years, had internalised Simmel's methodology which, it seems clear that this position represents a break with his former teacher.

In The Philosophy of Money, Simmel does not defend an uncritical relativism: rather, his is an absolute relativism. He gives the relative its due, proposing that truth emerges in the relationship between representations that can only be realised as an infinite construction whose conclusion can never be known. ${ }^{53}$ In specifying the absolute truth as a whole that cannot be known, he effects a transition between the relative and the absolute - by way of a passing mention of Spinoza:

$[\mathrm{O}]$ nly through the continuous dissolution of any rigid separateness into interaction do we approach the functional unity of all elements of the universe, in which the significance of each element affects everything else. Consequently, relativism is closer than one is inclined to think to its extreme opposite - Spinoza's philosophy - with its all-embracing substantia sive Deus. This absolute, which has no other content than the universal concept of being, includes in its unity everything that exists. All particular continuities and substantialities, all second-order absolutes, are so completely merged in that single absolute that one might say: all the contents of the world view have become relatives in a monism such as Spinoza's. The all-embracing substance, the only absolute that remains, can now be disregarded without thereby affecting the content of reality - the expropriator will now be expropriated, as Marx says of a process that is similar in form - and nothing remains but the relativistic dissolution of things into relations and processes. ${ }^{54}$

51 Simmel: The Philosophy of Money, p. 119 (»beängstigenden Widerspruch. [...] wenn jede als ein heuristisches Prinzip gilt, das mit der anderen in dem Verhältnis von Wechselwirkung und gegenseitigem Sich-Ablösen steht«, Philosophie des Geldes, p. 77).

52 Lukács: History and Class Consciousness, pp. 139-140 (Geschichte und Klassenbewußtsein, pp. 319-320).

53 Simmel: The Philosophy of Money, p. 119 (Philosophie des Geldes, p. 71).

54 Ibid., pp. 125-126 (»Eher liegt es in Wirklichkeit umgekehrt: durch die ins Unendliche hin fortgesetzte Auflösung jedes starren Fürsichseins in Wechselwirkungen nähern wir uns überhaupt erst jener funktionellen Einheit aller Weltelemente, in der die Bedeutsamkeit eines jeden auf jedes andere überstrahlt. Darum steht der Relativismus auch seinem extremen Gegensatz, dem 
Strictly speaking, then, Simmel defends a conception of the absolute as an unknowable nothing that is posited by the infinite reciprocity of reason, as it works through various contents. And on this basis, he believes it possible to cast it aside, or perhaps, to leave it as an object of mystical contemplation. This does not please Lukács. In words redolent of his critique of Simmel, noted above, he suggests that all relativism conceals the "the dogmatic position of those thinkers who likewise offered to explain the world from premises they did not consciously acknowledge and which, therefore, they adopted uncritically«. Lukács then argues:

For, from the standpoint of both logic and method, the ssystematic location of the absolute is to be found just where the apparent [conceptual] movement stops. The absolute is nothing but the fixation of thought, it is the projection into myth of the intellectual failure to understand reality concretely as a historical process. [...] And as long as the absolute survives in a system (even unconsciously) it will prove logically stronger than all attempts at relativism. For it represents the highest principle of thought attainable in an undialectical universe, in a world of ossified things and a logical world of ossified concepts. What these relativists are doing is to take the present philosophy of man with its social and historical limits and to allow these to ossify into an reternal limit [...] Actuated either by doubt or despair they thus stand revealed as a decadent version of the very rationalism or religiosity they mean to oppose. Hence they may sometimes be a not unimportant symptom of the inner weakness of the society which produced the rationalism they are >combating . But they are significant only as symptoms. It is always the culture they assail, the culture of the class that has not yet been broken, that embodies the authentic spiritual values. ${ }^{55}$

Spinozismus mit seiner allumfassenden substantia sive Deus, näher als man glauben möchte. Dieses Absolute, das keinen anderen Inhalt hat als den Allgemeinbegriff des Seins überhaupt, schließt demnach in seine Einheit alles ein, was überhaupt ist. Die einzelnen Dinge können nun allerdings kein Sein für sich mehr haben, wenn alles Sein seiner Realität nach schon in jene göttliche Substanz ebenso vereinheitlicht worden ist, wie es seinem abstrakten Begriff nach, eben als Seiendes überhaupt, eine Einheit bildet. Alle singulären Beständigkeiten und Substanzialitäten, alle Absolutheiten zweiter Ordnung sind nun so vollständig in jene eine aufgegangen, daß man direkt sagen kann: in einem Monismus, wie dem Spinozischen, sind die sämtlichen Inhalte des Weltbildes zu Relativitäten geworden. Die umfassende Substanz, das allein übrig gebliebene Absolute, kann nun, ohne daß die Wirklichkeiten inhaltlich alteriert würden, außer Betracht gesetzt werden - die Expropriateurin wird expropriiert, wie Marx einen formal gleichen Prozeß beschreibt - und es bleibt tatsächlich die relativistische Aufgelöstheit der Dinge in Beziehungen und Prozesse übrig. «, Philosophie des Geldes, pp. 84-85).

55 Lukács: History and Class Consciousness, pp. 187-188 (»Denn der Punkt, der dem Aufhören der Scheinbewegung in diesen Systemen logisch-methodisch entspricht, ist eben der ssystematische Ort $<$ des Absoluten. Das Absolute ist nichts anderes als die gedankliche Fixierung, die mythologisierend positive Wendung der Unfähigkeit des Denkens, die Wirklichkeit konkret als geschichtlichen Prozeß zu begreifen. [...] Und solange das Absolute im System (wenn auch unbewußt) mitgedacht ist, muß es den Relativierungsversuchen gegenüber das logisch stärkere Prinzip bleiben. Denn es vertritt das höchste Denkprinzip, das auf undialektischem Boden, in der Seinswelt der starren Dinge und der logischen Welt der starren Begriffe erreichbar ist; [...]. Denn diese Relativisten tun nichts anderes, als die gegenwärtige gesellschaftlich-geschichtlich gegebene Schranke der Weltauffassung des Menschen in die Form einer biologischen, pragmatistischen usw. ^ewigen`Schranke erstarren zu lassen. Auf diese Weise sind sie nichts mehr als 
When presented alongside Simmel's defence of absolute relativism, and with Lukács's critique of Simmel's culturally focused impressionism in mind, it seems clear that these lines were intended as much for Lukács's former teacher as anyone. Even Lukács's slip into moralising language - attributing relativism to doubt or despair and seeing it as a decadent, transitional product of culture in decline - brings to mind his early feelings of estrangement from Simmel's milieu and from Central European intellectual culture generally.

\title{
4. Simmel's rejoinder
}

\begin{abstract}
Being and becoming are the most general, formal, and inclusive formulations of the basic dualism that patterns all human beings: all great philosophy is engaged in founding a new reconciliation between them, or a new way of giving decisive primacy to one over the other. ${ }^{56}$
\end{abstract}

Lukács's philosophy culminated with praxis. This he understood in political terms, as the unity between the theory and practice of the proletarian movement, culminating in a decision, freely made by the proletariat (through the mediation of a revolutionary party and workers' councils), to make an insurrection and to remake the world. ${ }^{57}$ This praxis, for Lukacs, was supposed to overcome the unconscious, dead weight of the past - as embodied in reified institutions and social relations - as well as the reified future of utopianism, which projects the ethical structure of bourgeois society, in idealised form, into the future. Praxis was to do this by converging on the present - in the blink of an eye, as he described it in A Defence of History and Class Consciousness. ${ }^{58}$ And once there, praxis would knowingly create the new, finally uniting genesis with logic, in a process of continual mediation undertaken by an emancipated humanity. As he wrote, in a moment of almost religious excess:

eine sich in der Form von Zweifel, Verzweiflung usw. ausdrückende Dekadenzerscheinung jenes Rationalismus oder jener Religiosität, denen sie zweifelnd gegenüberstehen. Sie sind deshalb zuweilen - ein geschichtlich nicht unwichtiges Symptom dafür, daß jenes gesellschaftliche Sein, auf dessen Boden der von ihnen `bekämpfter Rationalismus usw. entstand, bereits innerlich problematisch geworden ist. Sie sind aber nur als solche Symptome bedeutsam. Die wirklichen geistigen Werte hat ihnen gegenüber stets die von ihnen bekämpfte Kultur, die Kultur der noch ungebrochenen Klasse repräsentiert.", Geschichte und Klassenbewußtsein, p. 374, emphasis in the original).

56 Simmel: Schopenhauer and Nietzsche, pp. 176-177.

57 For more on Lukács's philosophical discussion of Lenin's revolutionary realpolitik, see López: Lukács: Praxis and the Absolute, Chs. 5-7.

58 Lukács: A Defence of History and Class Consciousness, p. 55. 
As long as man concentrates his interest contemplatively upon the past or future, both ossify into an alien existence. [...] Man must be able to comprehend the present as a becoming. He can do this by seeing in it the tendencies out of whose dialectical opposition he can make the future. Only when he does this will the present be a process of becoming, that belongs to him. Only he who is willing and whose mission it is to create the future can see the present in its concrete truth. ${ }^{59}$

\section{Simmel also wished to locate truth in the present. In The Philosophy of Money, he defended the present as the only basis for knowledge of the past:}

No matter how many transformations and quantitative changes are required, the present, which is the indispensable key to the past, can itself be understood only through the past; and the past, which alone can help us to understand the present, is accessible only through the perceptions and sensibilities of the present. ${ }^{60}$

Simmel's present was, however, quite different from Lukács's, notwithstanding the fact that only five years intervened between the former's death and the publication of History and Class Consciousness. Insofar as Simmel took an sinward road in order to resolve the antinomies he wrestled with, he did not discover it in the experience of reification endured by the proletariat in the work day, as Lukács did. Rather, Simmel encountered it via an analysis of the extremes of modern culture. In the essay The Conflict of Modern Culture, he diagnosed the ground of these antinomies as the tension between form and life:

What we are is, it is true, spontaneous life, with its equally spontaneous, unanalysable sense of being, vitality and purposiveness, but what we have is only its particular form at any one time, which, as I have stressed above, proves from the moment of its creation to be part of quite a different order of things. [...] This paradox becomes more acute, more apparently insoluble, to the degree that the inner being which we can only call life tout court asserts its formless vitality, while at the same time inflexible, independent forms claim timeless legitimacy and invite us to accept them as the true meaning and value of our lives - that is the paradox is intensified, perhaps, to the degree to which culture progresses. ${ }^{61}$

59 Lukács: History and Class Consciousness, p. 204, emphasis in the original (»Solange der Mensch sein Interesse - anschauend kontemplativ - auf Vergangenheit oder Zukunft richtet, erstarren beide zu einem fremden Sein [...]. Erst wenn der Mensch die Gegenwart als Werden zu erfassen fähig ist, indem er in ihr jene Tendenzen erkennt, aus deren dialektischem Gegensatz er die Zukunft zu schaffen fähig ist, wird die Gegenwart, die Gegenwart als Werden, zu seiner Gegenwart. Nur wer die Zukunft herbeizuführen berufen und gewillt ist, kann die konkrete Wahrheit der Gegenwart sehen.", Geschichte und Klassenbewußtsein, p. 392, emphasis in the original).

60 Simmel: The Philosophy of Money, p. 119 (»Wie viele Umbildungen und Quantitätsänderungen auch dazu erforderlich seien, jedenfalls ist die Gegenwart, die uns der unentbehrliche Schlüssel für die Vergangenheit ist, doch nur durch diese selbst verständlich, und die Vergangenheit, die allein uns die Gegenwart verstehen läßt, ohne die Anschauungen und Fühlbarkeiten eben dieser Gegenwart überhaupt nicht zugängig.", Philosophie des Geldes, p. 76).

61 Simmel: The Conflict of Modern Culture, pp. 89-90 (»Wir sind zwar das Leben unmittelbar und damit ist ebenso unmittelbar ein nicht weiter beschreibliches Gefühl von Dasein, Kraft, 
Prior to the First World War, and in its early years, Simmel did not discern an intellectual pathway out of the tension between form and life. He instead proposed two lifestyles or character types that radicalise either side of the antinomy. The ascetic saint radicalises an ideal of life, as whole and flourishing, against a culture whose forms have hypertrophied to the point where they cannot sustain a meaningful life. The ascetic saint is thus a nihilistic revolutionary who takes aim at a culture as a whole in the name of a perfect, absolutely meaningful future. The opposite type is the specialist fanatic. Although quite aware of the sickness of their culture and its diminished ability to cultivate life, the specialist fanatic defends the cultural forms that sustain their own fragmented specialisation by designating a particular enemy. In so doing, the call for the regeneration of a specific national culture. This type thus idealises a previous golden age and promises that it will be reborn if the sickness of culture is purged. ${ }^{62}$

While the former type corresponds more closely to the left - and to Lukács - the latter corresponds to the right and is a prototype for reactionary or fascist irrationalism. Nevertheless, both types share a central contradiction: Both locate the truth of culture and life in a transcendent future. Thus, they transform the present into a pernicious chasm of meaninglessness that must be bridged by violence: revolutionary violence, in the former and reactionary terror in the latter. Lukács's philosophy of praxis falls into precisely the same chasm. Because the model for his concept of praxis was drawn from the Russian Revolution, he fetishized a moment of praxis that had already slipped away by 1923. Yet, the immediate purpose of History and Class Consciousness was political, namely, to arm the proletarian movement with a theory adequate to reviving this praxis in Western Europe. This relies on the promised return of revolutionary praxis. And yet, because Lukács would have the concept of praxis bear the weight of absolute knowing, the absence of praxis (or, more correctly, the incompleteness and blindness of praxis) in the present in fact imprisoned his philosophy of praxis in a nostalgic-messianic nihilism. This was a more radical nihilism than Simmel's earlier absolute relativism, to be sure. However, it is also a more dogmatic

Richtung verbunden; aber wir haben es nur an einer jeweiligen Form, die, wie ich schon betonte, im Augenblick ihres Auftretens sich einer ganz anderen Ordnung angehörig zeigt [...]. Dieser Widerspruch wird krasser und scheint unversöhnlicher in dem Maße, in dem jene Innerlichkeit, die wir nur Leben schlechthin nennen können, sich in ihrer ungeformten Stärke geltend macht, in dem andererseits die Formen sich in ihrem starren Eigenbestand, ihrer Forderung unverjährbarer Rechte als der eigentliche Sinn oder Wert unserer Existenz anbieten, vielleicht also in dem Maße, in dem die Kultur gewachsen ist.", Der Konflikt der modernen Kultur, pp. 45-46). 
nihilism. By dismissing the absolute as constitutively not-knowable in The Philosophy of Money, Simmel authored what might be described as a philosophy of finitude: if the absolute is infinitely distant, all that is left is the self-negating movement of finite contents through themselves. In nominating money (or later, culture) as an ultimately aesthetic heuristic, Simmel acknowledged the incompleteness and ultimate groundlessness of his philosophy. Lukács, on the other hand, elevated one finite contents the praxis of October 1917 - to the status of an infinite. In this manner, he tasked praxis with the overcoming of the antinomies of bourgeois thought and with the conscious creation of the new - heroic tasks, even for a triumphant socialist revolution. Yet this obscured the element of violence in the October Revolution and the decision of a sovereign, Lenin, that initiated it under a mythologisation of the consciousness of the proletariat. It may well be said that Lukács selected praxis for his heuristic. Yet, he did so on an absolute basis, and thus made of it a political theology: He erected a model of past praxis as an >ought over and against the situation he saw around him, in the 1920s. To be sure, he paid close attention to the concrete mediations of practical politics. Nevertheless, as Hegel argued, religion $»$ is any elevation of the finite to the infinite, when the infinite is conceived as a definitive form of life ${ }^{63}$

The problem, then, is not with the contents of Lukács's philosophy of praxis (namely, his specific views and philosophical, sociological or political concepts) but with its form. It is a philosophy in the Hegelian sense insofar as it has the absolute as its substance and insofar as it rejects finite, relative being as something ultimate and absolute. Yet because Lukács did not regard his philosophy of praxis philosophically, that is, because he saw philosophy as something to be overcome by the higher truth of political praxis, his did not reflect the philosophical form of his philosophy. He was trapped, then, in what Hegel called representative thought. And insofar as Lukács covertly fetishized a particular, finite contents, he did not carry the principle of philosophy to its conclusion. Thus, Hegel would have regarded his infinite as a spurious one:

It is only the spurious infinite which is the beyond, because it is only the negation of the finite posited as real - as such it is the abstract, first negation; determined only as negative, the affirmation of determinate being is lacking in it; the spurious infinite, held fast as only negative is even supposed to be not there, is supposed to be unattainable. However, to be thus unattainable is not its grandeur but its defect, which is at bottom the result of 
holding fast to the finite as such as a merely affirmative being. It is what is untrue that is unattainable and such an infinite must be seen as a falsity. ${ }^{64}$

In The View of Life, Simmel overcame this problem. ${ }^{65} »$ Life as Transcendence «, the first chapter, proposes a concept of life that can overcome the hypostatisation of the past and the future. Simmel identifies the ground for this movement as life itself, which exists in an absolute present:

As long as past, present, and future are separated with conceptual precision, time is unreal, because only the temporally unextended (i.e., the atemporal present) moment is real. But life is the unique mode of existence for whose actuality this separation do not hold [...] Time is real only for life alone. ${ }^{66}$

Because time destroys all values, all values are transient and finite. And yet, the notion of an absolute present, partly informed by Nietzsche's eternal return, allows us to recover the infinite quality of value: if past and future are grasped as polyvalent perspectives born of the present, values can be known as infinite. To posit the finitude of one set of values is simply to tear them down in favour of another; the passing away of the finite is equally the creation of the new.

By holding fast to qualities amidst their falling away, life also demonstrates its power to establish and transcend all boundaries. Simmel means this in a simple sense, namely, that life needs separations and divisions: larger, smaller, behind, in front, here, there, food, not-food, safe, unsafe. Humans, however, possess an additional capacity to reflect on the boundaries we create. By even naming a boundary, we already concede that we are beyond it. So, for every finite measure we propose, we state in principle that we can exceed it, if only negatively. This, of course, is close to the position that Simmel expressed in The Philosophy of Money. Now, however, he goes one step further, stating that we »deny the boundary the moment we know its one-sidedness, without ceasing thereby to stand within it «. ${ }^{67}$ The prize of this insight is the philosophical knowledge that the infinite is both external and our own possession and creation: it emerges within the movement through finite contents. Thus, our souls combine infinite and finite, becoming and being: "With every exertion of the will in the here and now, we demonstrate that a threshold between `now and the , future is just not real, and that as soon as we assume such a threshold, we stand at once

65 This is not to assert that Simmel became a late convert to Hegelian philosophy. To fully consider this possibility, a much more detailed, Hegelian reading of The View of Life would be necessary. Simmel: The View of Life, p. 8.

67 Ibid., p. 5. 


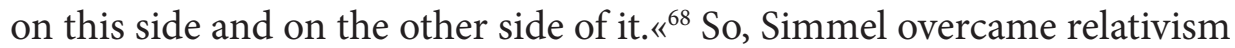
by understanding that the power of negativity at its core is our power and a necessary precondition for everything valuable: "By virtue of our highest, self-transcending consciousness at any given moment, we are the absolute above our relativity. « ${ }^{69}$

This does not deny that acts of valuation, necessary for life, can freeze over and tyrannize life. Insofar as we do not recognize our own activity or thought in an act of valuation, it can become transcendent and metaphysical. And when objectified in external structures (say, the economy, academia, the Church, the state), practices which generate values become reified and blindly self-perpetuating. Yet the advantage of Simmel's final perspective is not that it promises a final overcoming of all estrangement. Rather, his philosophy of life can sustain what is qualitative about each overarching value (say, beauty, truth, divinity, justice) without reducing them to each other - or worse, to indifference. In this manner, Simmel builds a conceptual universe that can sustain totalities of meaning, religious, aesthetic, technical, political, while allowing them to flourish concurrently, conflicting, coexisting and cross-polinating, while resisting the impulse to collapse them into each other. While these worlds of meaning contribute to and draw from the absolute in their turn, insofar as they claim to exclusively possess or fully know the absolute, they produce a life-denying after-world and implicitly negate themselves. ${ }^{70}$ When this insight is applied to Lukács's philosophy of praxis, it means that the concept of praxis - which promises a revaluation of political values - can be encountered in light of both its finitude and its ability to produce the new, that is, to evoke the infinite as it creates a future in the negation of the past - all in the blink of an eye. If this can be done without fetishizing praxis as a finitized infinite, then genuinely radically transformative political praxis may be possible. If this conceptual possibility became actual, it would signify the formation of a polity in which the acting and judging consciousness may forgive each other.

During and after the 1920s, Lukács condemned Simmel's argument as an example of irrationalist >Lebensphilosophie $<.{ }^{71}$ Yet, Simmel's viewpoint is capable of saving the ethical and anti-formalistic, de-reifying impulse of philosophy of praxis. Simmel writes:

69 Ibid.

70 Ibid.

71 Cf. Lukács: The Destruction of Reason (Germ. Die Zerstörung der Vernunft). 
Everything varying, or by definition unique, or gliding in the continuity of life without assignable boundaries; everything that eludes any subordination under a preexisting law and likewise eludes conceptual sublimation to a universal law - all this now finds an Ought over it, because the latter itself is a life and retains its continuing form. And indeed because the demand does not confront life as a rigid once-and-for-all, everything we have ever done and everything we have ever been obligated to is the condition under which our ethical ideal life rises to the crest of what is currently obligated. Just as each pulse-beat of a living being is determined by all its past pulse-beats, likewise nothing can be lost in this process, which makes not only the act but also the Ought of every moment into the heir and the bearer of responsibility of all that we have ever been, done, and been obligated to. Thus is finally completed the differentiation - the freeing, so to speak - of the elements of whose amalgamation in Kant's ethics these pages have so often spoken: that only the actual, but not the ideal-normative, can be individual, and only the universal, not the individual, can be lawful - these are the linkages whose undoing has been accomplished on this long path, so that the linkage of individuality and lawfulness could be accomplished. ${ }^{72}$

Philosophy of praxis erects an »Ought « over and against the present - and locates the truth of this ought in a past that is recollected. Yet, the recollection was that of an individual philosopher - Georg Lukács - whose political conviction was deeply subjective and profoundly ethical. And insofar as this was the case, he spoke not for a universal, but for an individual; specifically, an individual who lived under a self-imposed, non-actual ideal-normative concept. The desublimation of the concept of praxis - which was here accomplished by way of Simmel's philosophy of life - dissolves its mythical from, revealing the individual articulation of the philosopher. In so doing, it prepares the individual to take responsibility for his actions and to live ethically without subsuming life under an ought and to participate in and contribute to a universal law. This was, in fact, the ultimate goal of Lukács's philosophy of praxis.

\section{Conclusion}

A number of incidental observations flow from this argument. Firstly, if it is true that a speculative standpoint can be derived from Lukács and Simmel, and more broadly, by way of the antinomies of neo-Kantian fin de siècle philosophy, then Lukács's pessimistic historicization of bourgeois philosophy is further undermined. This is not, of course, to say that all eras or cultures within modernity can generate speculative philosophy. But it does assert that philosophy did not come to an end with Hegel. From this it flows that Marx and Marxism did not put an end to or complete philosophy, effecting a turn towards historical, social or political knowledge in its place. Rather, 
philosophy is vouchsafed a continued role as a sphere of reflective knowledge that may cultivate actors who can practice a thinking that reconciles between the antinomies that structure social being. Secondly, if indeed Simmel developed a speculative standpoint, he did so without relying, at least in his published writing, extensively on Hegel's own philosophical system. Indeed, his articulation of the speculative standpoint is quite distinct from Hegel's: it is less systematising, less certain about the immanent logic of history and rather more expressionist. A full comparison of Simmel's philosophy of life with Hegel's system would no doubt raise further differences - and likely contradictions. Yet, presuming that Simmel's final position is indeed speculative (and, for that matter, presuming that Lukács's position is implicitly speculative) then the particularities and achievements of their philosophies must represent a synthesis between their own, finite, human particularities and the historical period whose truth they both incompletely, yet profoundly, expressed. Absolute knowing, after all, is not synonymous with the absolute. It is the practice of philosophy and does not demand the repetition of the same form or contents, as though this were possible at all. Seen in this manner, a diversity of pathways into speculative thought and the possibility of different articulations of if enriches the cultural wealth of spirit while rewarding the successful philosopher with the joy of having produced something both universally true and irreducibly particular. To make a contribution like this is to win a kind of eternal life that flourishes not in an afterworld, but in the minds of living people: So long as we discern new insights in Lukács and Simmel's work, their legacy will never lapse into flat self-identity, but will instead generate diversity within unity.

This implies a third observation, a hypothesis. In a culture that produces antinomic or dialectical thought, there are multiple pathways to a speculative standpoint. If true, it is good news indeed for Hegelians. No longer need it be their infinite duty to reconstruct the system of their teacher - unless, of course, that is what they desire. Rather, we can encounter and make the new. On a broader level, the more that the social totality is capable of generating speculative knowledge, the greater chance humanity has of knowing itself in its imperfection and finitude, and in so doing, approaching the true infinite. Finally, if it is possible to elevate Lukács's thought to the status of philosophy proper, then a broader promise is issued for Marxism as a whole. In the aftermath of the failure of every one of its major currents, if Marxism confesses to having idolised this or that finite contents, as a theoretical culture situated within modernity, the socialist movement may grasp the form of the true infinite and rise to philosophy proper, thus sustaining a freer, more rational and more radical praxis. So, Simmel's final gift to Lukács 
may well be a gift for Marxist philosophy as a whole: a contribution to the reformation of Marxism for which Gillian Rose called and a step towards founding a Marxian absolute idealism.

\section{References}

Feenberg, Andrew: The Philosophy of Praxis. London: Verso 2014.

Gluck, Mary: Georg Lukács and his Generation. Cambridge, MA: Harvard University Press 1991.

Hegel, Georg Wilhelm Friedrich: Fragment of a System (1800). In: Hegel: Early Theological Writings. Philadelphia: University of Pennsylvania Press 1996, pp. 309-320.

Hegel, Georg Wilhelm Friedrich: The Science of Logic. New York: Routledge 2010.

Hegel, Georg Wilhelm Friedrich: Encyclopedia of the Philosophical Sciences in Basic Outline, Part I: Science of Logic. Cambridge, UK: Cambridge University Press 2015.

Hegel, Georg Wilhelm Friedrich: The Phenomenology of Spirit. Cambridge, UK: Cambridge University Press 2018.

Kavoulakos, Konstantinos: Lukács's Philosophy of Praxis. London: Bloomsbury Academic 2018.

Kavoulakos, Konstantinos: What is Reification in Georg Lukács's Early Marxist Work? »Thesis Eleven« 157 (April 2020), pp. 44-46.

López, Daniel: Lukács. Praxis and the Absolute. Leiden: Brill 2019.

López, Daniel: Lukács. The Antinomies of Bourgeois Philosophy and the Absolute. »Thesis Eleven« 157 (April 2020), pp. 110-132.

Löwy, Michael: Georg Lukács: From Romanticism to Bolshevism. London: Verso 1979.

Lukács, Georg: History and Class Consciousness. London: MIT Press 1972 (Geschichte und Klassenbewußtsein. In: Georg Lukács: Frühschriften II. Darmstadt, Neuwied: Luchterhand 1977).

Lukács, Georg: Selected Correspondence, 1902-1920. New York: Columbia University Press 1986.

Lukács, Georg: Georg Simmel. »Theory, Culture and Society« 8/3 (1991), pp. 145-150.

Lukács, Georg: A Defence of History and Class Consciousness. London: Verso 2002.

Lukács, Georg: Soul and Form. New York: Columbia University Press 2010 (Die Seele und die Formen. Bielefeld: Aisthesis 2011).

Lukács, Georg: The Destruction of Reason. New Delhi: Akar Books 2016.

Moir, Cat: The Archimedean point: Consciousness, Praxis, and the Present in Lukács and Bloch. »Thesis Eleven« 157 (April 2020), pp. 3-23.

Rose, Gillian: Hegel Contra Sociology. London: Verso 2009.

Rose, Gillian: From Speculative to Dialectical Thinking: Hegel and Adorno. In: G. Rose: Judaism and Modernity. London: Verso 2017, pp. 75-86.

Simmel, Georg: The Adventurer. In: Georg Simmel - On Individuality and Social Forms. Chicago: University of Chicago Press 1971, pp. 187-198.

Simmel, Georg: Schopenhauer and Nietzsche. Chicago: University of Illinois Press 1991.

Simmel, Georg: Metropolis and Mental Life. In: Simmel on Culture. Ed. David Frisby. London: Sage 1997, pp. 174-186.

Simmel, Georg: The Concept and Tragedy of Culture. In: Simmel on Culture. Ed. David Frisby. London: Sage 1997, pp. 55-74. 
Simmel, Georg: The Conflict of Modern Culture. In: Simmel on Culture. Ed. David Frisby. London: Sage 1997, pp. 75-89 (Der Konflikt der modernen Kultur. München, Leipzig: Von Duncker \& Humblot 1918).

Simmel, Georg: The Philosophy of Money. Oxford: Taylor and Francis 2011 (Philosophie des Geldes. G. Simmel: Gesammelte Werke, Bd. 1. Berlin: Duncker \& Humblot 1958).

Simmel, Georg: The View of Life. Four Metaphysical Essays with Journal Aphorisms. Chicago, London: Chicago University Press 2015.

Sun Lee, Yoon: Temporalized Invariance: Lukács and the Work of Form. In: Lukács: The Fundamental Dissonance of Existence. Aesthetics, Politics, Literature. Eds. Timothy Bewes, Timothy Hall. London: Bloomsbury 2011, pp. 17-35.

Westerman, Richard: Lukács's Phenomenology of Capitalism. Cham: Palgrave Macmillan 2019. 